\title{
Antecedents of destination brand experience
}

\author{
Miska Irani Tarigan ${ }^{1}$, Arlina Nurbaity Lubis ${ }^{2 *}$, Endang Sulistya Rini ${ }^{3}$, Beby Karina Fawzeea \\ Sembiring ${ }^{4}$ \\ Faculty of Economic and Business, Universitas Sumatera Utara, Medan, Indonesia ${ }^{1,2,3,4}$ \\ iranitarigan@gmail.com ${ }^{l}$, arlina@usu.ac.id $^{2 *}$
}

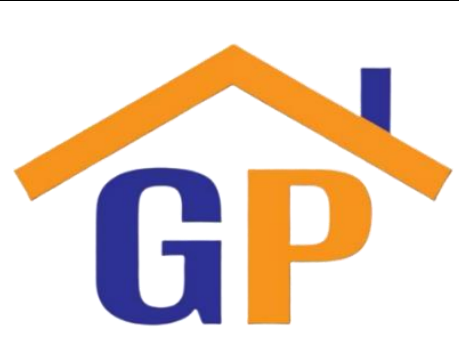

Article History

Received on 13 February 2021

Revised on 16 February 2021

Accepted on 22 February 2021

\begin{abstract}
Purpose: The tourism sector is the leading sector for Indonesia's foreign exchange earnings. The Indonesian government has established six National Tourism Strategy Areas, including Lake Toba, North Sumatra. Development in the Lake Toba tourist area has been carried out, but it does not automatically bring tourists to visit the Lake Toba Tourism Area. The researcher intended to know the factors of the tourist brand experience in Lake Toba. Therefore, this study aims to confirm the factors obtained from a literature study.
\end{abstract}

Research methodology: The research methodology used is a qualitative study, namely Focus Group Discussion. Participants in the Focus Group Discussion are Government Representatives, Tour Guides, Travel Agencies, and domestic tourists' representatives.

Results: The study results should add to the Tourist Self-expression as a new precursor to the destination brand experience.

Limitation: The study did not involve hospitality and other relevant governments to gain a broader perspective.

Contribution: The results of this study hope to contribute to references for tourism marketing.

Keywords: Brand experience, Destination branding, Tourism marketing, Lake Toba

How to cite: Lubis, A. N., Tarigan, M. I., Rini, E. S., \& Sembiring, B. K. F. (2021). Antecedents of destination brand experience. Journal of Sustainable Tourism and Entrepreneurship, 1(4), 293303.

\section{Introduction}

Place marketing refers to the various communication techniques used to sell premises and their attractions or products through identity and image construction. This involves four activities (Kotler, Heaider, and Rein, 1993). First, designing the right mix of community features and services. Second, establish attractive incentives for current and potential customers and users of their goods and services. Third, deliver on-site products and services in an efficient and accessible manner. Fourth, promote the place's values and image so that potential users are fully aware of this place's unique advantages. The last one is related to branding activities. Place branding emerged in the early 2000s as a distinct academic discipline. It was seen as a way in which countries and cities could control reputation due to increasing competition and global economic pressures. From a marketing perspective, a place or destination branding can be applied to any one or all types of locations and activities (Hakinson, 2010).

Destination Branding is defined as a series of marketing activities consisting of four actions. First, it supports creating names, symbols, logos, word signs, or other images that are ready to identify and differentiate a goal. Second, consistently convey the expectation of a memorable travel experience that is uniquely linked to the destination. Third, it serves to consolidate and strengthen the emotional connection between the visitor and the destination. Fourth, reduce consumer search costs and perceived risks. Collectively, this activity serves to create a destination image that positively affects consumers' choice of destination. (Blain et al. 2005). Destinations are considered as a mix of individual products and experience opportunities that combine to form the total experience of the area visited (Murphy, 
Pritchard, and Smith, 2000). Therefore, in creating experiences in the context of objectives, natural settings and city views become visual symbols of experience, while place names become brands (Morgan et al, 2010; Lumbanraja et al, 2017). Thus, marketing activities in destination branding are aimed at offering tourism destinations.

Schmitt (1999) suggests assessing a brand as a rich source of sensory, affective, and cognitive associations that result in a memorable and rewarding brand experience. Her experiences are identified in meaning (including aesthetic and sensory qualities), including mood and emotions, thinking (including analytical and imaginative thinking), acting (motor actions and behavioral experiences). Brakus et al (2009) break the brand experience into four dimensions, sensory, affective, intellectual, and behavioral. Sensory indicators measure the level of impressions made by brands that affect the senses. Wulandari (2016) Affective indicators include sentiment and emotions. Behavioral indicators measure body orientation and actions. Intellectual indicators involve thinking, curiosity and problem solving. Therefore, brand experience is a concept of emotional connection and combines cognitive and behavioral concepts. To investigate a brand experience in the context of a destination is unique because unlike a product or service where the offering comprises the majority of the goods or a large portion of the service, a travel destination can be thought of as a mixture of individual products and experiential opportunities that combine to form the total experience of the area visited (Murphy, Pritchard, and Smith, 2000). The research begins by searching the literature that suggests factors that may influence experiences

In the field of tourism, imagery is still being discussed as a stand-alone concept. The image in the discipline of tourism is defined as the perception of a place that is reflected by associations held in the memory of tourists (Cai, 2002). Research has begun to integrate destination images in tourism with the concept of branding (Qu, Kim and Im, 2010). The role of imagery is critical in each phase. Before the visit, imagery is undoubtedly the essential criterion for visiting or not visiting the destination (Buhalis, 2000; Qu, Kim, and Im, 2010). After experiencing a goal, customer satisfaction will depend on assessing the overall experience felt from the goal versus the anticipation of expectations and perceptions. Therefore, developing the right image for the destination will determine the brand's ability to satisfy visitors because it will allow the brand to develop realistic expectations and meet expectations (Morgan and Pritchard, 2004; Seaton, 1997)

The importance of service infrastructure in the experience of tourist destinations is also recognized by Crouch and Ritchie (2005). Service infrastructure including transportation services and related support service infrastructure which includes, for example: retail shopping facilities, food stores, garage / car maintenance, gas stations, pharmacies, bookstores, laundry, and salons. Another related discussion about infrastructure services at destinations is the collaboration of destination stakeholders to provide services. Tourism destinations consist of a variety of stakeholders with different market interests (Pike, 2007).

\section{Literature review and hypotheses development}

\subsection{Antecedents of destination brand experience}

The research begins by looking for literature that suggests factors that might influence experience. These factors are grouped into five categories: themes and images, social aspects, products and (or) service aspects, network-related aspects, and customers have their own values. Social aspects involve interactions happening in experience (Larsen, 2007; Murray, Foley, \& Lynch, 2010; Prayag et al, 2017). The product and service aspects are related to the offer in the experience setting, including the main attractions and activities at the destination. Aspects related to the network include support systems at the destination, such as accessibility, complementary services, and information availability. While the customer's own characteristics are related to personal reasons that influence an experience's purchasing decision. (Binkhorst, E., 2005; Situmorang, et al, 2019; Uriely et al, 2002). 


\subsubsection{Destination image}

The image in the discipline of tourism is defined as the perception of a place that is reflected by associations held in the memory of tourists (Cai, 2002; Chen \& Tsai, 2007; Chen et al, 2011; Chi \& Qu, 2008). The role of imagery is critical in each phase. Before the visit, imagery is undoubtedly the essential criterion for visiting or not visiting the destination (Buhalis, 2000; Qu, Kim, and Im, 2010). After experiencing a goal, the level of customer satisfaction will depend on the assessment of the overall experience felt from the goal versus the anticipation of expectations and perceptions. Therefore, developing the right image for the destination will determine the brand's ability to satisfy visitors because it will allow the brand to develop realistic expectations and meet expectations (Morgan and Pritchard, 2004; Seaton, 1997; Christian \& Elena, 2015)

\subsubsection{Destination infrastructure and support service}

Tourism products are experiences that result from a process where tourists use many services during their visit to a destination (Gunn, 1988). Gopalan and Narayan (2010) identified important extrinsic factors (Language, Cleanliness and Road Conditions) and intrinsic factors (tour operator services, viewing locations, travel options) along with several other factors (comfort of staying, friendliness of local residents, safety and road congestion) as an important dimension of service at the destination. Smith (2003) points out that the level of use or lack of infrastructure and technology in a destination determines features that can enhance the visitor's travel experience. (Choi et al, 2009)

The importance of service infrastructure in a tourist destination experience is also recognized by Ritchie and Crouch (2000). Service infrastructure including transportation services and related support service infrastructure which includes, for example: retail shopping facilities, food stores, garage / car maintenance, gas stations, pharmacies, bookstores, laundry, and salons. It is recommended that destinations be more effective when these services are abundant (Dwyer, 2001). Lack of appropriate infrastructure will affect tourist experiences (Murphy et al, 2000). In line with previous studies, Heath's destination competitiveness model (2003) states that enablers' provision is an important foundation of the model. Enablers are defined as infrastructure (airports, roads, signage, etc.) and management capabilities. This is a relevant factor for tourist decisions because inefficiencies often influence decision selection in infrastructure (Prideaux, 2000). Thus competitiveness is also determined by the infrastructure at the destination. In the marketing area, Frels, Shervani and Srivastava (2003) study defines networks into three categories: user, complete and producer networks.

\subsubsection{Destination interaction}

The literature has stated the importance of interaction in creating experiences (Boswijk et al., 2005; Mascarenhas et al., 2006; Moscardo, 2008; Poulsson and Kale, 2004). Interaction has the role of initiating experience, as Gentile and Spiller (2007) suggest that customer experience comes from a set of interactions between the customer and the product, company, or part of the organization, which provokes a reaction. Johnson (2006) also describes the quality of favorable interactions between tourists and local residents. More favorable tourist interactions with local hosts, a more positive perception of destination development. Previous research from Huang \& Hsu (2009) Pizam, Ureily (2005) found that closer interaction leads to more positive effects on experience satisfaction. Vengesayi and Mavondo (2004) also stated that the level of experience between guests and hosts is related to tourism experience.

According to Morgan et al (2010) there are three types of interactions in the social context of holiday travel: between tourists, between travel providers and services, and between tourists and local hosts. Therefore, interesting interactions in destinations in this study are called interesting interactions between tourists and other tourists, between tourists and service personnel and between tourists and local hosts.

\subsubsection{Destination attraction quality}

Middleton et al, (2009) refer to attractions as this section includes an explanation of the sampling frame and size, selection of respondents, interview techniques, and efforts to ensure the method's validity and reliability.enjoyment, entertainment and education. However, this definition is criticized for not 
accommodating illegal tourism sites that include major disaster sites, sites and prisons related to individual deaths (Leask, 2010). Thus this study follows the definition of Bhati and Pearce (2017) which states attraction as: "A site named with certain human or natural features that are the focus of visitors and management's attention".

Lelloltery (2018) put forward three major tourism attractions or typology approaches ideographic approach, organizational approach and cognitive approach. Ideographic approaches systematize tourist attractions according to observable features rather than abstract and universal characteristics. Ritchie and Crouch provide a classification based on an ideographic approach. All tourist attractions are divided into seven main categories: physiography and climate, culture and history, a mixture of activities, special events, entertainment, superstructure and market relations.

\section{Research methodology}

\subsection{Antecedents of destination brand experience}

There are two qualitative studies considered to achieve the goal: in-depth interviews and focus group discussions. In-depth interviews are unstructured, direct personal interviews where an experienced interviewer examines a single respondent to reveal the underlying motivations, beliefs, attitudes and feelings on a topic (Maholtra, 2007). FGD is a group discussion that is designed to learn about the subject's perceptions about a specified area of interest (Kaplowitz \& Hoehn, 2001). These two methods are not substitutes but complement each other.

This study uses FGD for several reasons. First is the topic consideration. Vacation experiences are not controversial or sensitive topics that need to be discussed one on one. Second, this research requires a form of interaction between respondents that is of concern because the literature finds evidence that social context is not only considered as an external source that can change behavior, but also functions in information development and in determining behavior (Bouchet, Patrick; Lebrun, Anne-Marie; Auvergne, Sarah, 2004). Third, the FGD was chosen because of the suitability and flexibility of the method. Because the purpose of this study is to confirm the introduction of the Destination Brand Experience, using FGD will generate the ideas of its predecessors and at the same time confirm the antecedents found in the literature. In addition to generating ideas, FGDs are also efficient in developing questionnaire items (Edmunds, H., 1999) (Nassar-Mcmillan, S. C., \& Borders: D., 2002).

\subsection{Field work}

This section explains the sampling frame and size, selection of respondents, interview techniques, and efforts to ensure the method's validity and reliability.

\subsubsection{Sampling framework and size}

The sampling framework for this FGD consists of two broad groups: service provider perspectives and customer perspectives. Travel agents and tour operators are chosen among other service providers (airlines, hoteliers, restaurant owners, etc.) because of their significant influence on tourist decisions. Research shows that tour operators and travel agents' perceptions about a destination will be a significant element that influences their decision to promote the destination, so that the image felt by travel intermediaries will be passed on to their clients. This interaction determines the competitiveness of a destination.

Service provider perspectives are translated into two FGD groups: the Travel Agent (TA) Group and the Tour Guide (TG) Group. Detailed criteria from the four FGD groups are explained as Table 1.

Table 1. Criteria the FGD group

\begin{tabular}{|c|c|c|c|}
\hline \multicolumn{2}{|c|}{ Service Provider } & \multicolumn{2}{c|}{ Customer } \\
\hline $\begin{array}{c}\text { Grup 1: Travel } \\
\text { Agent (TA) }\end{array}$ & $\begin{array}{c}\text { Grup 2: Tour Guide } \\
\text { (TG) }\end{array}$ & $\begin{array}{c}\text { Grup 3: Packaged } \\
\text { Tour Travellers } \\
\text { (PGT) }\end{array}$ & $\begin{array}{c}\text { Grup 4: Free } \\
\text { Independent Traveler } \\
\text { (FIT) }\end{array}$ \\
\hline $\begin{array}{l}\text { Minimum 3 years } \\
\text { experience, with } \\
\text { moderate - high levels }\end{array}$ & $\begin{array}{l}\text { Minimum 3 years } \\
\text { experience, with a high }\end{array}$ & $\begin{array}{l}80 \% \text { tourist } \\
\text { experience packed } \\
\text { by travel agents. }\end{array}$ & $\begin{array}{l}80 \% \text { tourist experience } \\
\text { packaged by }\end{array}$ \\
\hline
\end{tabular}




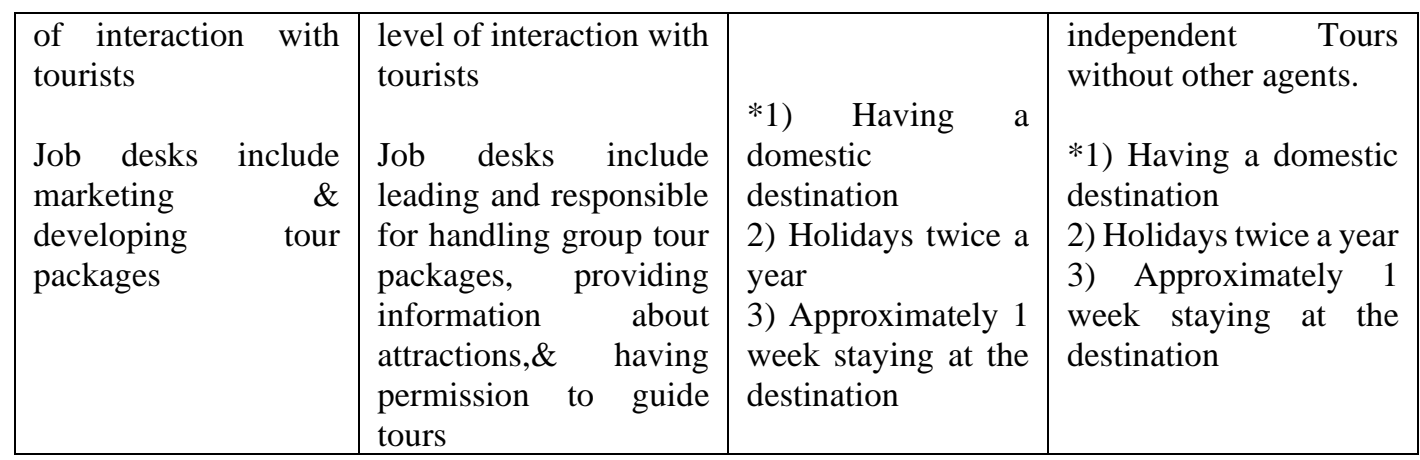

Source: FGDs Data

In this discussion, each group's size was between 5 and 7 participants, which contributed to the small FGD. Barbour and Kitzinger (1999) argue that, although orthodoxy emerged from the research literature, the market-determined that the ideal number of participants was between eight and twelve participants. Some of the references worked with groups of five to six participants, even up to 3 people. Participants were selected through interviews conducted with questionnaires prepared by researchers. The questionnaire was made based on each participant's criteria. The Screener Questionnaire is based on criteria for each participant. The recruitment process produced six participants for the Travel Agent group (TA code), six participants for the Travel Guide group (TG code), seven participants for the Packed Group Travelers (PGT code) and five participants for the Free Independent Traveler (FIT code). with service providers (TA and TG) conducted at FGD facilities, while interviewing tourists (PGT and FIT).

\subsubsection{Moderator and interview technique}

The researcher acts as a moderator in this focus group discussion. The decision to moderate directly was taken because of special industry knowledge, which was needed to guide the discussion process. In interviewing respondents, moderators use a more targeted approach to allow coverage of topics and detailed coverage of certain topics of interest in the time available (Stewart, Shamdasani and Rook, 2007)

\subsubsection{Validity and reliability}

Descriptive validity is related to the accuracy of fieldwork. Primary descriptive validity refers to what the researcher reports or hears (or touches, smells, and other senses) (Maxwell, 1992). While secondary descriptive validity refers to the validity of things that can be observed in principle, but what is inferred from other data. For example, things happen in the discussion room while the moderator is not present. In this study, recording the discussion to ensure the right conversation is reported, gives descriptive validity. Reliability is approached, not as a separate aspect of validity or to separate issues from validity, but on certain types of threats to validity (Maxwell, 1992). To take reliability countermeasures, the researcher uses the question guideline for discussion. In some questions, the definition is outlined to bring participants to the same level of understanding of the construct in question.

\section{Results and discussions}

Previous literature studies postulate the introduction, results and relationship of the Destination Brand Experience, which was confirmed in this FGD study. The results support the following antecedents: Quality of Destination Attractions, Destination Infrastructure and Support Services, Destination Imagery and Destination Interaction. In addition, Tourist Self Expression has emerged as one of the concepts in the discussion.

\subsection{Destination image}

For the destination brand the respondent began as a tagline and image, often by word of mouth, followed by the experience itself. The initial image is then rechecked for its actual performance in reality. After going on vacation, respondents will go through a process of checking and balancing whether the brand 
image and promise match reality. Respondents agreed that whatever the brand must be in accordance with the actual reality in the destination or not worthy of loyalty. Respondents agree that imagery triggers their curiosity to visit a destination. A positive and unique Destination Image can encourage them to buy a vacation. The shocking negative Destination Image might also trigger them to visit the destination in some cases. Literature studies that have been carried out indicate that a tourist destination's image is an important component that will be evaluated by pre-visit visitors (Keller, Parameswaran, Jacob, 2011). This finding confirms the uniqueness of the destination image as an antecedent of the Destination Brand Experience.

Image of Lake Toba with beautiful views, with a stunning caldera. Providing recreational facilities and water sports, can provide a quiet vacation, and provide options for challenging activities. There are places for family recreation in Lake Toba's tourist area, solo travelers or for meetings and business event recreation. The tourist area of Lake Toba is surrounded by seven districts with cultural diversity and values, therefore a visit to the Lake Toba area is rich in cultural values, hospitality and of course all of these will add to your vacation experience. The discussion also found that there were some negative images in the Lake Toba tourist area, including discomfort during transactions, dirty and jammed.

\subsection{Destination infrastructure and support service}

Of the five dimensions (size, future size expectations, compatibility, accessibility and quality), only two dimensions emerge; accessibility and quality. In the segment, the Destination Infrastructure and Support Services that are important and accessible are important for the holiday experience because they create a feeling of security and comfort. The study of Andereck, et al (2006) found that access to recreational areas can determine tourists' experience at a destination. Other factors include cleanliness of public facilities, road conditions, and clear road signs leading to attractions locations. Morgan (2006) states that local food and drink availability helps to strengthen the uniqueness and memories of experiences.

Following the Lake Toba development plan, infrastructure development and supporting facilities will be carried out in the Lake Toba tourist area. The construction of the toll road from Kuala Namo Airport to Parapat has reached Tebing Tinggi. Bridge construction and also the construction of ferry ports. The airports that are operated in the Lake Toba tourist area are Silangit and Sibisa airports. This opens up access for domestic and foreign tourists to come to Lake Toba more easily. The only access to destinations is still under repair, so that the highway roads are tidier, cleaner and more organized. Easy access for tourists to destinations is important to coordinate with various parties to visit destinations and adventures in tourist areas more easily and positively.

\subsection{Destination interaction}

This study confirms that the three types of Interaction Destinations (Travel Guides - Tourists, Tourists - Local Communities and between tourists) are an important part of creating a holiday experience. Tourist visits have a certain relationship and interact with human factors and will be a special attraction (Vengesayi and Mavondo, 2009). It is more specifically stated that the attitudes and sense of place cultivated by local residents significantly influence tourists' experience at the destination (Hakinson, 2010). Interaction of fellow tourists visiting the Lake Toba tourist area is carried out with their group friends, because tourists visiting Lake Toba are family. Then the interaction between tourists and officers at the destination, namely security officers, information officers, cleaners, tour and guide officers, and officers at travel agencies. The last interaction is the interaction of tourists with local residents. The local residents in the Lake Toba tourist area are of Batak ethnicity, so tourists who have the same ethnic background or can use the Batak language will find it easier to communicate or will be responded to better. In the framework of the Lake Toba tourist area as a National Tourism Strategic Area, it is necessary to have friendly interactions and, as far as possible, be able to communicate with domestic tourists from all over Indonesia and also foreign tourists.

In Suciati and Agung's research, 2016 stated that expressing one's emotions is an important part of the social mingling process. Furthermore, this study states that the Batak tribe in expressing their emotions can be said to be quite expressive, although not the most expressive. This is in line with the results of 
research conducted by Dewi (2005), according to him, people from the Batak tribe are known for their persistence, strong speaking style, courage and acting decisively. Therefore the Batak people prefer to be candid about the emotions they are feeling. This is basically formed from the Batak culture values that have since been embraced and passed on from generation to generation, namely dalih na tolu. The results of the discussions carried out confirmed that the expressions of local residents as hosts often become obstacles in communication with tourists.

\subsection{Destination attraction quality}

Attractions in the form of iconic attractions provide a reason to visit the destination in the first place. At the destination, attractions provide a platform to create experiences. After the trip, new attractions can be the reason for repeated visits. Thus, Destination Attraction Quality is one of the drivers of experience. $\mathrm{Xu}(2010)$ illustrates that the attraction point becomes a core accompanied by services, hospitality, freedom of choice, and involvement, making it a tourist attraction. Attractions in the Lake Toba tourist area already have a concept and a certain schedule. The attraction is a music festival. Attractions in the Lake Toba tourist area are rituals and traditional ceremonies, usually a combination of music and dance. This attraction is an exciting activity that can be done in the tourist area of Lake Toba.

All components of the Destination Brand Experience (sensory, affective, cognitive and behavior) are proven in this study, but the destination context provides a much broader concept than the experience generated from the stimulus that is part of the design and identity, packaging, and brand communication. Instead, it involves the entire environment from beginning to end. Thus, the Destination Brand Experience must be defined as the total experience of the tourists. In addition to confirmed antecedents, there is a new antecedent that has emerged strongly: tourist self-expression

In the FGD, destination personality traits did not emerge and respondents appeared to have difficulty linking goals with certain personality traits. But there is one related concept that comes strongly into conversation, self-expression. There are two of types of self-expression that appear in FGDs. First finding, is that vacation experiences help release or express themselves. According to Triandis and Suh in Huang, 2009 defines personality as "the configuration of cognition, emotions, and habits that are activated when situations stimulate their expression". In this context, the holiday situation stimulates self-expression or self-actualization reacts to experience and produces an image of the goal being evaluated. However, when asked to express a destination with personality, respondents showed confusion and difficulty in coming up with a personality that represented the goal.

Other forms are related to having holiday experiences as a way to express themsekc, make a statement, or prove a destination's image. This opinion emerged strongly in the discussion. The literature review found support from research by Phau and Lau, 2001 which showed that when a brand commands high preferences, the personality that the consumer likes actually has an influence on the perceived brand personality - provided that the consumer has built a positive relationship with the brand and then strengthens his personality to brand. The results of the FGDs confirm the different characteristics of domestic tourists and foreign tourists. The difference is in terms of tourist interest in knowledge of destinations, where foreign tourists are generally more interested and pay attention to all information relating to destinations. In contrast to domestic tourists, there is less interest and attention to destination knowledge and information. Domestic tourists are interested in selfie activities at destinations.

In this context, respondents try to express themselves through purchasing holiday experiences to reflect their own personalities. This implies that not the experience translated into personality traits that describe a destination. However, a person's personality needs to express when he is at the destination becomes the destination's personality for certains travellers. This results in brand personality eventually becoming personified brand image, not brand personality. This research does not prove for brand personality as a result of experience. Rather, it is the need for self-expression that is found as a potential motivator and antecedent for creating Destination Brand Experience. 


\section{Conclusion}

Study of antecedents Destination brand experience in the Lake Toba Tourism Area pays special attention to enhancing brand experience that will ultimately increase repeat visits' intensity, recommending to others. Antecedents of previous research are destination image, destination infrastructure and service support, destination attraction and destination interaction. The results of the research add antecedents that is the self-expression of tourists becomes something to note. The results of this study confirm the factors of the brand experience in the destination, if the image of the Lake Toba tourist area is positive, infrastructure and support services are adequate and following standards, pleasant interactions between fellow tourists, with officers and local residents, quality attractions and Positive self-expression of tourists will enhance the brand experience in the tourist area of Lake Toba. Positive brand experiences in destinations will provide positive recommendations to friends and family, as well as on their social media and the desire to return to the Lake Toba tourist area. Creating a pleasant brand experience in the Lake Toba tourist area's destination is the interdependence of all parties, between district governments, between business actors and other shareholders. It is hoped that with the large number of tourists and visiting tourists again, the tourism sector in the Lake Toba tourist area will stimulate the local community's economy, impacting the national economy.

\section{Limitation and study forward}

This study used a group discussion method where the discussion participants were the North Sumatra Provincial Government Marketing Development Division, BPODT Marketing Team, and the Tourism Driving Community Team (Tour Guide also Tour and Travel). Broader perspective will be obtained by involving Hospitality also other relevant governments. This research is a qualitative study that has not used qualitative study testing tools, such as Nvivo.

\section{Acknowledgement}

The author is grateful to the Ministry of Research and Technology/National Research and Innovation Agency (Kemenristek/BRIN) of Indonesia for the tremendous support for the 2020 fiscal year

\section{References}

Andereck, K., Bricker, K. S., Kerstetter, D., \& Nickerson, N. P. (2006). Connecting experiences to quality: understanding the meanings behind visitors' experiences. In G. Jennings, Quality Tourism Experiences (p. 85). Oxford: Butterworth - Heinnemann.

Barbour, R. S., \& Kitzinger, J. (1999). Focus group research. politics, theory and practice. London: Sage Publication.

Bhati, A., \& Pearce, P. (2017). Tourist attractions in Bangkok and Singapore; linking vandalism and setting characteristics. Tourism management, 63, 15-30.

Binkhorst, E. (2005). The co-creation tourism experience. Sitges: Whitepaper Co-creation.

Blain, S., Levy, S., \& Ritchie, J. (2005). Destination branding: insight and practices from destination management organizations. Journal of Travel Research, 328-338.

Boswijk, A., E.Peelen, \& T.Thijssen. (2005). Een nieuwe kijk op de experience economy, betekeniisvolle belevenissen. Amsterdam: Pearson Education Benelux.

Bouchet, Patrick; Lebrun, Anne-Marie; Auvergne, Sarah (2004). Sport tourism consumer experiences: a comprehensive model. Journal of Sport Tourism, (9), 127-140.

Brakus, J.J., B.H. Schmitt, and L. Zarantonello. 2009. Brand experience: What is it? How is it measured? Does it affect loyalty? Journal of Marketing 73(3), 52-68.

Buhalis, D. (2000). Marketing Destination of the Future. Tourism Management, 21(1), 97-116.

Cai, L. A. (2002). Cooperative branding for rural destinations. Annals of tourism research, 29(3), 720 742.

Chen, C-F., Tsai, DC. (2007). How destination image and evaluative factors affect behavioral intention? Tourism Management, 28(4), 1115-1122. http://dx.doi.org/10.1016/j.tourman. 2006.07.007

Chen, C-M., Chen, S.H., \& Lee, H.T. (2011). The destination competitiveness of Kinmenn's tourism industry: Exploring the interrelation -ships between tourist perceptions, service performance, 
customer satisfaction and sustainable tourism. Journal of Sustainable Tourism, 19(2), 247-264. http://dx.doi.org/10.1080/09669582.2010.517315

Chi, C.G.Q., \& Qu, H. (2008). Examining the structural relationships of destination image, tourist satisfaction and destination loyalty: an integrated approach. Tourism Management, 29(4), 624-636. http://dx.doi.org/10.1016/j.tourman.2007.06.007

Choi, G., Parsa, H.G., Sigala, M., \& Putrevu, S. (2009). Customers' environmental concerns \& behaviors in the lodging industry: a comparison between Greece \& the United States. http://dx.doi.org/10.1080/15280080902946335 Journal of Quality Assurance in Hospitality \& Tourism, 10(2), 93-112.

Christian, S., \& Elena, R. (2015). Creative tourism in destination brand identity. International Journal Vallis Aurea, 1(1), 75-83

Crouch, G. I., \& Ritchie, J. B. (2005). Application of the analytic hierarchy process to tourism choice and decission making: a review and illustration applied to destination competitiveness. Tourism Analysis, 10(1),17-25

Dewi, L. Zahrasari. (2005). Pengalaman, ekspresi, dan kontrol marah pada orang batak dan Jawa. Jurnal Psikologi Fakultas Psikologi UNIKA Atma Jaya, 16(2).

Dwyer, L., \& Kim, C. W. (2001). Destination competitiveness: development of a model with application to Australia and the Republic of Korea. Canberra: Department of Industry Science and Resources.

Edmunds, H. (1999). The focus group research handbook. NTC Business Books, Chicago, 7-8.

Frels, J. K., Shervani, T., \& Srivastava, R. K. (2003). The intergrated networks model: explaining resource allocations in network markets. Journal of Marketing, 67, 29-45.

Gentile, C., \& Spiller, N. a. (2007). How to sustain the customer experience: an overview of experience components that co-create value with the customer. European Management Journal, 25(5), 395410.

Gopalan, R., \& Narayan, B. (2010). Improving customer experience in tourism: a framework for stakeholder collaboration. Socio- Economic Planning Science, 44, 100-112.

Gunn, C. A. (1988). Tourism planning (No. Ed. 2). Taylor \& Francis.

Hakinson, G. (2010). Location branding: a study of branding practices of 12 english cities. Journal of Brand Management, 9(2), p.127

Huang, H .H.-C (2009). Self-identity and consumption: a study of consumer personality, brand personality and brand relationship. University of Warwick.

Huang, S., \& Hsu, C. H. (2009). Effects of travel motivation, past experience, perceived constraint, and attitude on revisit intention. Journal of travel research, 48(1), 29-44.

Johnson, J. D. (2006). Residents' perceptions of tourism development over the early stages of the TALC. (Vol. 1). The Tourism Area Life Cycle.

Kaplowitz, M. D., \& Hoehn, J. P. (2001). Do focus group and individual interviews reveal the same information for natural resource valuation? Ecological Economics, 36(2001), 237-247.

Keller, KL, Parameswaran, MG, \& Jacob, I., 2011, Strategic brand management: Building, measuring, and managing brand equity. Pearson Education India.

Larsen, S. (2007). Aspects of psychology of the tourist experience. Scandinavian Journal of Hospitality and Tourism, 7(1). 7-18. http://dx.doi.org/10.1080/15022250701226014

Leask, A. (2010). Progress in visitor attraction research: towards more effective manage -ment. Tourism management, 31(2) 155-166.

Lelloltery, H., Pudyatmoko, S., Fandelli, C., \& Baiquni, M. (2018). Study of coral reef for marine ecotourism development based on region suitability and carrying capacity in Marsegu Island Nature Tourism Park, Maluku,Indonesia. Biodiversitas Journal of Biological Diversity, 19(3), 1089-1096.

Lumbanrajam Prihatin., Lubis, Arlina N., Hasibuan, \& Baby K. (2017) Sustaining Lake Toba's Tourism: Role of Creative Industry, Green Tourism Marketing and Tourism Experience. Journal ajba, 12(1), 9 .

Malhotra, N. K. (2007). Marketing research an applied orientation. New Jersey: Pearson Prentice Hall. 
Mascarenhas, O. A., Kesavan, R., \& Bernacchi, M. (2006). Lasting customer loyalty: a total customer experience approach. Journal of consumer marketing.

Maxwell, J. A. (1992). Understanding and validity in qualitative research. Harvard Educational Review, 62(3), 279.

Middleton, V. T., Fyall, A., Morgan, M., \& Ranchhod, A. (2009). Marketing in travel and tourism 4th edition. Oxford: Buttenworth - Heinemann.

Morgan, G. (2006). Images of organization. (Updated edition) thousand oaks, CA: Sage Publications, pp. $1-520$

Morgan, N., \& Pritchard, A. (2004). Meeting the destination branding challenge. In N. Morgan, A. Prittchard, \& R. Pride, Destination Branding Creating the Unique Destination Proposition, 2nd edition (p. 60). Oxford: Elsevier Butterworth-Heinemann.

Morgan, M., Lugosi, P., \& Ritchie, B. J. (2010). The tourism and leisure experience. Bristol: Channel View Publication.

Moscardo, G. (2008). Sustainable tourism innovation: challenging basic assumptions. Tourism and Hospitality Research, 8(1), 4-13.

Murray, N., Foley, A., \& Lynch, P. (2010). Understanding the tourist experience concept. Ireland: Waterford Institute of Technology.

Murphy, P., Pritchard, M. P., \& Smith, B. (2000). The destination product and its impact on traveller perceptions. Tourism management, 21(1), 43-52.

Nassar-Mcmillan, S. C., \& Borders: D. (2002). Use of focus groups in survey item development. The Qualitative Report, 7(1) March.

Poulsson, S. H., \& Kale, S. H. (2004). The experience economy and commercial experiences. The marketing review, 4(3), 267-277.

Prayag, G., Hosany, S., Muskat, B, \& Del Chiappa, G. (2017). Understanding the relationships between tourists' emotional experiences, perceived overall image, satisfaction, and intention to recommend. Journal of travel research, 56(1), 41-45. http://dx.doi.org/10.1177/20047287515620567

Pike, S. D. (2007). Consumer-based brand equity for destinations: Practical DMO performance measures. Journal of Travel \& Tourism Marketing, 22(1), 51-61.

Phau, I., \& Lau, K. C. (2001). Brand personality and consumer self expression: single or dual carriageaway? The Journal of Brand Management, 8, 428.

Prideaux, B. (2000). The role of the transport system in destination development. Tourism management, 21(1), 53-63.

Qu, H., Kim, L. H., \& Im, H. H. (2010). A model of destination branding: Integrating the concepts of the branding and destination image. Tourism Management, 1-12.

Rein, I., Kotler, P., \& Haider, D. (1993). Marketing places: attracting investment, industry, and tourism to cities, states, and nations. The Free Press.

Ritchie, J. R. B., \& Crouch, G. I. (2000, June). Are destination stars born or made: Must a competitive destination have star genes. In Lights, Camera, Action-31st Annual Conference Proceedings.

Schmitt, Bernd. (1999). Experiential marketing. The Free Press Now York

Seaton, A. V., \& Palmer, C. (1997). Understanding VFR tourism behavior; the first five years of the United Kingdom tourism survey. Tourism management, 18(6), 345-355.

Situmorang, et al, (2019). Brand experience analysis - How it relates to brand personality, value, satisfaction and loyalty in TV brands? International Journal of Civil Engineering and Technology.

Smith, S. W. (2003). Labour economics. Routledge.

Stewart, D. W., Shamdasani, P. N., Rook, \& W, D. (2007). Focus Group Theory and Practice: Second Edition. USA: Sage Publication.

Suciati, Rina, dan Agung, Ivan Muhammad, 2016, Perbedaan Ekspresi Emosi pada orang Batak, Jawa, Melayu dan Minangkabau. Jurnal Psikologi, 12(2), Desember 2016

Ureily, N. (2005). The tourist experience: conceptual development. Annals of Tourism Research, 199216.

Uriely, N., Yonay, Y., \& Sim Chai, D. (2002). Backpacking experience: A type and form analysis. Annals of Tourism Research, 29(2), 520-538. http://dx.doi.org/10.1016/S0160-7383(01)00075-5 
Vengesayi, S., \& Mavondo, F.T. (2004). Aspects of Reputation and Human Factors as Determinants of Tourist Destination Attractiveness. Marketing Accountabilities and Responsibilities: Proceedings of the Conference. ANZMAC.

Wulandari, Nuri. (2016). Brand experience in banking industry: direct and indirect relationship to loyalty. Expert Journal of Marketing, 4(1), 1-9, 2015 @ 2016 The Author. Published by Sprint Investify. ISSN 2344-6773.

Xu, J. B. (2010). Perceptions of tourism products. Tourism Management, 607-610. 